\title{
1Do customer perceptions of innovation matter in industrial markets?
}

\begin{abstract}
Perceptual customer constructs can be central to leverage market intelligence for optimizing customer relationships. The purpose of this paper is to contribute to our understanding of the relationship between perceptual customer metrics that relate to relationship quality (i.e., customer orientation, customer satisfaction, attitudinal loyalty, customer influence on supplier innovation) and behavioral outcomes (i.e., customer account profitability, share of wallet). The paper integrates stated and revealed preference data from a multinational mechanical engineering firm and its global customer base. Results from latent class analysis and fractional logistic regressions highlight both the role of customer perception heterogeneity, and that of nonlinearities between perceptual constructs and behavioral metrics, for targeting behavioural outcomes. They also suggest that attitudinal loyalty and customer satisfaction are highly relevant aspects of relationship quality with respect to share of wallet. However, fractional logistic regression results also indicate that customer perceptions of the supplier's product innovativeness, and perceptions of customer influence on supplier innovation, are likely not relevant aspects of relationship quality.
\end{abstract}

Keywords: perceptual customer constructs, satisfaction, loyalty, share of wallet, innovation perceptions 


\section{Introduction}

The examination of perceptual customer constructs has generated a large body of work within the customer relationship and customer value management literature, with a focus on customer satisfaction, retention and profitability metrics (e.g. Verhoef, Van Doorn \& Dorotic 2007; Flint, Blocker \& Boutin 2011; Keränen \& Jalkala 2013; Lemon \& Verhoef 2016; Kumar \& Reinartz 2016). To impact such metrics, companies have aimed at influencing customer perceptions and engagement, by employing a variety of resources and capabilities (von Hippel 1982; Dwyer, Robert, Schurr \& Oh 1987; Narver \& Slater 1990). Notably, to influence customer perceived benefits of a supplier's offering and thus address customer-perceived value, companies have used different ways to integrate customer feedback mechanisms (e.g. Lapierre 2000; Ulaga \& Charcour 2001). Accordingly, a growing literature has investigated perceptual customer metrics and their impact on financial and non-financial performance indicators (e.g., Gruca \& Rego 2005; Gupta \& Zeithaml 2006; Sorescu \& Sorescu 2016).

Yet despite extensive work on perceptual customer measures and a detailed understanding of the multidimensional nature of customer engagement (e.g. Brodie et al. 2011, 2013; Kumar et al. 2015; Beckers et al. 2017; Harmeling et al. 2017), we still lack understanding of customer engagement in the context of B2B innovation (Lilien 2016). Furthermore, since relatively few empirical studies have explored customer engagement by directly incorporating perceptual constructs in behavioral outcomes (e.g., Kamakura et al. 2002; Gupta et al. 2006; Kumar et al. 2013), recent work continues to highlight that more work with behavioural data would be preferable, especially in analyses of customer satisfaction and share of wallet (e.g. Buoye 2016).

The purpose of this paper is to look beyond traditional perceptual customer metrics such as customer orientation, customer satisfaction, and attitudinal loyalty, and explore to what extent customer 
perceptions of innovation can be associated with customer relationship quality in terms of behavioural loyalty and customer account profitability. In line with previous work (e.g., Keiningham et al. 2003, 2005; Cooil et al. 2007; Buoye 2016), our analysis draws on Anderson \& Mittal's (2000) satisfaction-repurchase-profitability chain framework, its adaptation to share of wallet (e.g. Keiningham et al., 2005; Cooil et al., 2007), and its anchoring in attitude-behavior relations models (e.g. Fishbein \& Ajzen 1975). Considering that relational assets can be converted into customer value (Srivastava et al. 1998), we also invoke the resource-based-view (Wernerfelt 1984; Barney 1991) to examine the relationship between perceptual customer metrics and behavioural outcomes. Our paper aims to contribute to the literature on perceptual constructs of customer satisfaction, customer loyalty and absolute perceptual metrics (e.g., Gupta et al. 2006; Buoye 2016; Kumar et a. 2016; Mittal et al. 2017). Notably, the importance of customer satisfaction to facilitating repurchasing and the link between repurchase intentions and share of wallet (SOW) in B2B markets is well established (e.g., Keiningham et al. 2003; Cooil et al. 2007; Keiningham et al. 2007; MeyerWaarden 2007; Voss et al. 2010). However, our innovation focus from the perspective of the customer puts us apart from an extensive literature that has explored the relationship between customer satisfaction and customer loyalty, both attitudinal and behavioral (e.g. Fornell et al. 1996; Szymanski et al. 2001; Gupta et al. 2006; van Doorn et al. 2008; Walsh et al. 2008; Naumann et al. 2009; Williams et al. 2011; Dagger et al. 2012; Kumar et al. 2013; Buoye 2016), and from customer value management works with a focus on customer behavior toward innovations (e.g. Zhang et al. 2016).

Empirically, this paper contributes by exploring components of customer relationship quality with regard to behavioral loyalty and customer account profitability, accounting for customers' innovation perceptions of the supplier, specifically regarding customers' perception of their influence on supplier innovation, and accounting for customers' perceived product innovativeness 
of the supplier. We integrate stated and revealed preference data, thereby providing a joint analysis of perceptual constructs with behavioral outcomes. This joint analysis is owing to customer responses from a global customer base associated with a given supplier. The supplier in question is a multinational mechanical engineering firm, headquartered in Europe. ${ }^{1}$ Noting the relevance of the global mechanical engineering sector in terms of its fundamental role to most branches of industry (Steiert 2008; Gardner 2016), and its central role to the EU economy with mechanical engineering being one of the largest industrial sectors in terms of number of enterprises, employment, production, and the generation of added value (EC 2016), we consider that the study is potentially relevant to a wider range of manufacturing firms. This paper aims also to contribute with its methodological approach. Although previous regression-based analyses have accounted for associations between perceptual customer metrics and business performance metrics including SOW (e.g., Anderson et al. 2000; Keinigham et al. 2003), our paper is, to the best of our knowledge, the first application of fractional logit regression methods to consider allocation fractions of wallets in relation to customer perceptual intensities. Whereas the literature on observable customer metrics has a long history of using a variety of allocation and choice models (e.g., Guadagni \& Little 1983; Tellis 1988), a limited use of such models is found in the literature on perceptual constructs in customer relationship work (e.g., Kamakura et al. 2005).

\section{Literature and hypotheses}

Customer analysis research has focused on a number of unobservable customer constructs, such as customer perceptions (e.g., service quality), customer attitudes (e.g., customer satisfaction) and behavioral intentions (e.g., intentions to purchase) (e.g., Woodruff 1997; Gupta et al. 2006;

\footnotetext{
${ }^{1}$ The focal firm in question is a diversified mechanical engineering enterprise that shares similarities in product portfolio and global reach with companies such as Bosch Rexroth AG, Linde AG, Eaton Corporation, Parker-Hannifin Corporation, or Emerson Climate Technologies.
} 
Tomczyk et al. 2016). Our paper links unobservable constructs with observable ones, i.e. behavioural loyalty (SOW) and a focal firm's profitability of a given customer account. The following sections will discuss these relationships conceptually and empirically, deriving several hypotheses. This discussion will centre around customer perceptions and customer involvement, drawing from two frameworks that could be linked through customer value driving competitive advantage (e.g. Arnould 2008; Woodruff 1997). First, Anderson \& Mittal's (2000) model underlying a satisfaction-repurchase-profitability sequence (and its adaptation to SOW, e.g. Keiningham et al., 2005; Cooil et al., 2007), and their anchoring in attitude-behavior relations models (Fishbein \& Ajzen 1975; Ajzen et al. 1980; Eagly et al. 1993; Mittal et al. 2001). Second, considering customer orientation and customers' perceived degree of involvement in supplier innovation potentially as an intangible asset embedded in customer-supplier relationships, and assuming that such relational assets can be converted into customer value (Srivastava et al. 1998), we invoke the resource-basedview (RBV; e.g. Barney 1991; Wernerfelt 1984). Drawing on these two frameworks, we aim to contribute to a micro-perspective of the 'black box' of perceptual B2B customer metrics (Gupta et al. 2006), and the call for more work toward a better understanding of the micro-foundations of the RBV (e.g., Foss 2011; Barney et al. 2011).

To gauge the costs and benefits of greater customer involvement from the perspective of the focal firm, suitable measurements are required (Keränen \& Jalkala 2013). Suppliers have thus frequently integrated customers into their knowledge-generating process through perception surveys (e.g., Dunphy \& Herbig 1995; Woodruff 1997), as the derived perceptual customer metrics can provide insights into the extent to which a focal firm's value proposition and capabilities are met (Day \& Wensley 1988; Oliver 1999; Verona 1999; Gupta et al. 2006; Carlson et al. 2015). As part of supplier-customer relations, customer value perceptions have also proved valuable in that customer 
value anticipation has been found to be a strong driver of satisfaction and loyalty (e.g. Flint et al. 2011). Further, customers' value perceptions have been considered highly important for a conceptualization of customer-perceived value (Ulaga et al. 2001: 528), while such customer value has been viewed to enable firms to receive Ricardian rents (Peteraf 1993), and drive competitive advantage (Woodruff 1997). Customer perceptions have thus proved useful for defining relationship value with suppliers (Ulaga et al. 2006), whereby a supplier may assist the customer's value creation processes through resource provision (Grönroos 2011; Ritter et al. 2012). Ample evidence suggests that an inclusion of customers in innovative processes may derive more customer-centred products (Füller \& Matzler 2007), improve mutual understanding (von Krogh et al. 2000) and lead to greater innovation performance (e.g., Prahalad et al. 2004; Desouza et al. 2008; Foss et al. 2011; Kostopoulos et al. 2011; Gemser et al. 2015; Kazadi et al. 2016; Park et al. 2017). A number of costs have, however, also been associated with greater market orientation (e.g., von Hippel 1982; O'Cass et al. 2012; Smals et al. 2012; Najafi-Tavani et al. 2016). In particular, costs associated with greater customer involvement in innovation may include higher development times (Greer \& Lei 2012) as well as an increase of coordination costs (Almirall et al. 2010). In light of the above discussion around behavioral loyalty, attitudinal loyalty, customer satisfaction, and customers' perceptions of a supplier's innovativeness, Figure 1 aims to guide the reader on these constructs, as we seek to explore them further in developing the following hypotheses.

Figure 1 about here

\subsection{Behavioral loyalty and profitability}

The theory of reasoned actions (Ajzen et al. 1980) implies that attitudes influence behavioral intentions and subsequent behavior. The relationship between such behaviour (e.g. repurchasing) 
and business performance (e.g. profitability) is widely supported (e.g., Keränen et al. 2013; Keiningham et al. 2015a). More specifically, on the basis of previous theoretical frameworks and empirical evidence, more recent work proposes that SOW be substituted in place of intentions in the chain of effects from customer satisfaction to customer profitability, such that the chain is expected to go from satisfaction to SOW to revenue to profit (Anderson et al. 2000; Mittal et al. 2001; Keiningham et al. 2015a: 269, Figure 11.2.). Thus far, an extensive literature has focused on the positive link between behavioral loyalty and corporate profitability (e.g., Reichheld \& Sasser 1990; Reichheld 1996; Reinartz et al. 2002; Garland 2004; Reinartz et al. 2015). Yet as Reinartz et al. (2002) note, increasing loyalty does not necessarily lead to an increase in the profitability of a customer account, since loyalty often comes at a cost. In particular, we have evidence which points to a mediated non-linear relationship between perceptual customer constructs and a focal firm's profitability, where customer revenue can correlate negatively with customer profitability for unprofitable consumer segments (Keiningham et al. 2005). Further evidence also suggests a close and positive yet non-linear relationship between SOW and customer profitability in a longitudinal study context (Larivière 2008). In sum, the evidence seems to suggest that the relationship between behavioral loyalty and profitability can be non-linear and require the focal firm to take a longer-term perspective, as some customers may become profitable only over time (Reinartz et al. 2015). In light of the above theoretical rationale and empirical evidence, we thus propose the following hypothesis:

H1: A change in behavioral loyalty is non-linearly associated with profitability of a given customer account, with positive association at higher levels of loyalty.

\subsection{Perceptual customer metrics and profitability}

\section{Customer satisfaction}

Srivastava et al. (1998) have developed a conceptual framework that captures the linkages between customer satisfaction and the creation of shareholder value, treating customer relationships as 
market-based assets that increase the residual value of cash flows. This line of satisfaction-profit chain modelling has been developed further by Anderson et al. (2000), emphasizing that the links in the satisfaction-profit chain can be expected to be asymmetric and nonlinear with increasing returns. To explain the origins of this asymmetry with increasing returns, Anderson et al. (2000) argue that changes in the positive-performance domain can have a greater impact on satisfaction than changes in the negative-performance domain, as a function of a customer's location of her reference point (Kahneman 1992). In the words of Mittal et al. (1998), supplier performance is evaluated based on relative performance changes rather than on absolute performance changes. To support their conceptual underpinnings, Anderson et al. (2000) summarize supporting evidence of an asymmetric and non-linear relationship from B2B marketing, healthcare, airline, telecoms, and automotive industries. The related quality-profitability-emphasis framework by Rust et al. (2002), which puts forward that firms seeking to maximize financial returns can emphasize customer satisfaction (revenue emphasis), efficiency (cost emphasis), or both (dual emphasis), has been extended by Mittal et al. (2005). Mittal et al. (2005) show that those firms achieving a dual emphasis perform better financially in the long run. Overall, the positive association between customer satisfaction and shareholder value appears robust, though to vary by industry (e.g. Anderson et al. 2004; Gruca et al. 2005; Williams et al 2011; Simmons 2015; Larivière et al. 2016). In an experimental study focusing on willingness-to-pay and satisfaction, Homburg et al. (2005) provide further support for nonlinearities and increasing returns. The review by Reinartz et al. (2015) of the various satisfactionloyalty studies consolidates the consensus on a non-linear and asymmetric relationship. Interestingly, they also put forward the concept of customer delight (e.g. Jones \& Sasser 1995; Oliver, Rust \& Varki 1997), to further justify the frequently observed increasing returns at higher satisfaction levels. Recent work has also highlighted the robustness of a positive relationship in the longer term, documenting customer satisfaction and long-term stock returns (Fornell et al. 2016; 
Sorescu et al. 2016), further supporting the increasing returns conjecture at higher levels of satisfaction. In light of the above support for a non-linear and partly positive relationship between customer satisfaction and financial returns, we propose the following hypothesis:

H2a: A change in customer satisfaction is non-linearly associated with the profitability of a given customer account, with positive association at higher levels of satisfaction.

\section{Customer orientation}

The overriding objective in market and thus customer orientation is the maximization of appropriable value creation relative to competition (e.g., Narver et al. 1990; Jaworski \& Kohli 1993; Foss \& Lindenberg 2013). Since such value creation can enable firms to generate Ricardian rents and drive competitive advantage (Peteraf 1993; Woodruff 1997), we could anticipate a positive relationship between customer orientation and account profitability, hence firm performance (Narver et al. 1990). Based on double-dyad interviews of Japanese firms as well as for a sample of UK SME's, Deshpandé et al. (1993) and Appiah-Adu \& Singh (1998), respectively, identify such a positive relationship between customer orientation and profitability. Drawing further on the RBV, Wang et al. (2016a) and Atuahene-Gima (1996) show that customer orientation can significantly enhance performance in manufacturing and service firms, as supplier collaboration can function as an important resource for innovation. Evidence from small firms suggests furthermore a moderating influence of risk-taking, innovativeness, and opportunity focus on the relationship between customer orientation and firm success (Brockman et al. 2012). More recent evidence using fuzzy set analysis reinforces the notion that highly performing firms configure themselves around their customer orientation (Frambach et al. 2016). Yet in the absence of specifics on the nature of the relationship between customer orientation and account profitability, we propose:

$H 2 b$ : A change in customer orientation is positively associated with the profitability of a given customer account. 


\section{Perceived innovativeness}

Analyses of the role of a supplier's innovativeness as perceived by its customers have received far less attention, compared to the role of supplier perceptions of innovation related to financial performance in supplier-buyer relationships (Ellis et al. (2012) and Jean et al. (2014) for evidence from the automobile sector; Wang et al. (2016a) for evidence from Chinese enterprises). This is somewhat surprising in the face of a growing literature on the measurement of customer-perceived value (e.g., Ulaga et al. 2001; Ulaga 2003; Ritter et al. 2012). It may also be surprising, since Sampson \& Spring's (2012) conceptual analysis puts forward an extended-capabilities view of customers as a basis for supplier-customer innovation in supply chains. Similarly, the lack of research focus on innovativeness as perceived by customers may be striking, since recent work has highlighted that the outcome from customization also depends on perceived customer participation (Wang et al. 2016b). Yet what does existing research suggest on the relationship between customerperceived benefits related to innovation, relationship value and financial performance? Considering a supplier's product innovativeness as perceived by its customers, the creation of relationship value is likely a function of both customer-perceived benefits and costs of a supplier relationship (Ulaga et al. 2006; Blocker et al. 2011; Lindgreen et al. 2012). Having created such relationship value, customer value could be expected to drive customer share (Cannon \& Homburg 2001; Eggert et al. 2010). Furthermore, from Eggert et al.'s (2010) view of customer value being a fundamental driver of customer share in business markets, we could conjecture that customer value (and perceived product innovativeness of the supplier in our case) could also be expected to be positively associated with account profitability as long as customers can appropriate some returns to higher supplier product innovativeness. More specifically, we might expect participation of customers in innovative practices to come at a high marginal cost to suppliers and customers early on in building and 
coordinating a supplier-customer relationship (e.g. Almirall et al. 2010; Greer \& Lei 2012), but then to lead to increasing returns to customer investments in relationship value in the longer term (e.g. Mittal et al. 2001; Homburg et al. 2005). Such nonlinearity might also be expected from Ritter et al.'s (2012) analysis of perceptual data, as this suggests that change-related relationship functions, including customer innovativeness, have a non-linear, inverted u-shaped impact on relationship value. Taking the above rationale into account, we might expect that customers' perception of the extent to which they can influence the supplier's innovativeness has a nonlinear relationship with the profitability of customer accounts (first negative, then positive as a function of increasing returns to relationship investment). Based on the above conjectures, and in the absence of more specific empirical evidence regarding the nature of non-linearity, the above observations lead us to:

H2c: A change in perceived product innovativeness is non-linearly associated with the profitability of a given customer account, with positive association at higher levels of perceived innovativeness.

\subsection{Customer orientation and product innovativeness of the supplier}

\section{Customer orientation}

The review of Zablah et al. (2004) on customer relationship management (CRM) work has established that CRM success cannot be achieved without customer orientation. We could expect that customer orientation is ultimately contributing to CRM success through increasing SOW (as reflected in Hypothesis 1c., Dorsch et al. 1998: 132), also noting the anticipated positive SOWprofitability link (e.g. Garland 2004; Larivière 2008; Mittal et al. 2001; Keiningham et al. 2015a), and building on the observed relationship between customer orientation and profitability (e.g. Narver et al. 1990). Conceptually, customer orientation has also been considered to be part of market orientation (Narver et al. 1990), involving the discovery of latent customer needs and impacting firm performance (Atuahene-Gima 1995). Taking this rationale further, customer orientation could be 
motivated with the RBV (Barney 1991) through at least three related arguments. First, in terms of the value of customer orientation as an intangible asset in contributing to supplier value and supplierbuyer relationships (e.g. Eisenhardt et al. 1996; Walter et al. 2001; Baxter et al. 2004; Wang et al. 2016a). In particular, Wang et al. (2016a) take an RBV perspective and explore how customer orientation may lead to strategic actions that improve resources - such as supplier collaborations for new product development, thereby driving firm performance. Second, we note the potential for increasing the value of supplier-buyer relationships when tacit knowledge is created, contributing to sustained resource heterogeneity and competitive advantage due to the inability to easily replicate such knowledge (Dierickx \& Cool 1989; Schroeder et al. 2002; Shamsie et al. 2013). And third, we have evidence that customer orientation can affect employee engagement (e.g. Anaza \& Rutherford 2012), and thus a supplier's key internal resource base, its human capital resources (Barney 1991; Kumar \& Pansari 2015, 2016). To motivate a firm's human capital basis is highly important, considering also that employee engagement has in turn been found to impact customer engagement, and consequently firm performance (Harmeling et al. 2017; Pansari \& Kumar 2017). In sum, taking the above RBV rationale into account, greater customer orientation could be expected to contribute to improved relationship quality and sustained competitive advantage with a given supplier. With such RBV rationale in mind, we could expect that customer orientation matters for supplier performance (Deshpandé et al. 1993) and that customers increase their expenditure on such suppliers, raising the SOW (Hooley et al. 1998). In the absence of specific evidence on the nature of this relationship (non-linearity), we invoke Anderson et al.'s (2000) framework underlying the satisfaction-repurchase-profitability sequence, its adaptation to SOW (Keiningham et al., 2005; Cooil et al., 2007) and its projections of increasing returns to higher levels of satisfaction, particularly increasing returns for the satisfaction-behavior link (Mittal et al. 2001). Taking the above evidence and conceptual underpinnings into account, we therefore propose: 
H3.a.: A change in perceived customer orientation of the supplier is positively and nonlinearly associated with SOW.

\section{Perceived product innovativeness}

Expanding on the above conjectures regarding perceived product innovativeness (section 2.2.), we anticipate that a customer's perception of the supplier's product innovativeness is a relevant aspect of relationship quality (Ford 1980; Dorsch et al. 1998). Furthermore, we expect that raising relationship quality and perceived customer participation may not only impact employee engagement (Anaza et al. 2012; Kumar et al. 2016), but also entice the customer to allocate a greater share of its purchases to a given focal supplier. In the absence of empirical evidence on how perceived innovativeness relates to retention or performance, we conjecture once more from Anderson et al. (2000) and its adaptation to SWO that the innovativeness-SOW link is also likely non-linear with increasing returns, as for the satisfaction-behavior link (Mittal et al. 2001). These considerations lead us to formulate the following hypothesis:

H3.b.: A change in customers' perceived product innovativeness of the supplier is positively and non-linearly associated with SOW.

\subsection{Customer's perceived influence on supplier innovation}

When a customer perceives scope to influence supplier innovations, we could expect this to contribute to the customer's increased perceived appropriability of returns to his relationship investment with the supplier (e.g. Grant 1991; Kleinaltenkamp et al. 2015), and to greater attractiveness of the customer to the focal supplier, due the underlying democratizing of innovation (von Hippel 2005). It is thus of interest to note that customer attractiveness to a given supplier has been found to help attaining preferential resource allocation from the supplier (Pulles et al. 2016). Further, the perceived capabilities of suppliers to innovate could be considered as an important part of a supplier's capability profile (Möller \& Törrönen 2003). These considerations suggest not only 
that customers' perceived influence on supplier innovation is potentially a relevant aspect of supplier collaboration and thus a resource from an RBV perspective, but also that such increased supplier attractiveness could lead a given customer to allocate a greater revenue share to this supplier. Furthermore, recent work has also shown that customer involvement in a supplier's innovation activities is reflected in a customer's perceived value of the supplier-buyer relationship, which can ultimately influence the supplier's financial performance (Arslanagic-Kalajdzic et al. 2015). On the one hand, this could be considered to further strengthen the case for taking an RBV perspective, in that such intangible assets as part of the supplier-buyer relationship (customer involvement in supplier innovation) can matter for competitive advantage (Srivastava et al. 1998; Baxter et al. 2004). On the other hand, this finding on financial performance from Arslanagic-Kalajdzic et al. (2015) reinforces our expectation from the Anderson et al. (2000) satisfaction-repurchaseprofitability chain, and from previous evidence on the positive SOW-profitability link (e.g., Garland 2004; Larivière 2008; Keiningham et al. 2015a), namely that perceived influence on supplier innovation is positively associated with SOW.

Furthermore, increased customer attractiveness to a focal supplier could be further rationalized with attitude-behavior relations models (Fishbein et al. 1975; Ajzen et al. 1980; Eagly et al. 1993), since these have been found to explain that customers' perceived behavioral control (customer's perceived influence on supplier innovation, in our case) can contribute to attitude toward remaining in a supplier-customer relationship (Guo et al. 2009). Linking such attitude to remain in the relationship with SOW, Blut et al. (2016) have shown that switching costs as part of buyer-seller relationships in B2B markets can impact SOW (Blut et al. 2016). In sum, switching behavior and thus relationship quality (Ford 1980) is likely impacted by customers' perceived influence on supplier innovation: customers who perceive that they have a high influence on their supplier's innovation activities 
could be expected to have more confidence into the suppliers' capabilities, and thus into rent earning capability of supplier-based internal scarce resources leading to sustainable competitive advantage (Hooley et al. 1998). In the absence of earlier evidence on the nature of the relationship between perceived innovation influence and SOW (non-linearity), the above observations lead us to:

H4: A change in customers' perceived influence on supplier innovation is positively associated with SOW.

\subsection{Customer satisfaction, attitudinal and behavioral loyalty}

\section{Customer satisfaction}

The importance of customer satisfaction for facilitating repurchasing, and the link between repurchase intentions and SOW in B2B markets is conceptually supported by attitude-behavior relations models (Fishbein et al. 1975; Eagly et al. 1993) and Mittal et al.'s (2001) model underlying a satisfaction-repurchase-profitability sequence, suggesting a non-linear relationship where loyalty investments may be recovered in the longer term. Empirically, there is ample evidence for a positive and non-linear relationship between customer satisfaction and SOW, from mostly banking and retail sector firms (e.g. Gupta \& Zeithaml 2006, Generalization 6; van Doorn et al. 2008; Williams et al. 2011; Buoye 2016). Such evidence is also complemented by experimental insights which suggest that customer satisfaction increases customers' willingness to pay (Homburg et al. 2005). Overall, the evidence is nevertheless inconclusive as to the nature of the non-linear relationship, in particular in regard to possible asymmetry (Reinartz et al. 2000, 2002; Reinartz et al. 2015). In light of the above conceptual rationale and empirical observations from sectors other than mechanical engineering, we propose to explore the following hypothesis:

H5.a: A change in customer satisfaction is positively and non-linearly associated with SOW. 


\section{Attitudinal loyalty}

Attitudinal loyalty, in terms of a customer's willingness to engage in a long-term relationship with the focal firm (Oliver 1997), can be positively related to customers' willingnes to develop their relationship with the focal firm (Dwyer et al. 1987), and to SOW, also when customer prioritization is pursued (Homburg et al. 2008). In light of the above observations, and in the absence of specific expectations regarding the nature of the (non-linear) relationship, we propose:

H5.b.: A change in attitudinal loyalty is positively associated with SOW.

\section{Methods}

\subsection{Data collection and descriptive statistics}

The stated preference data comes from a B2B customer perception survey conducted by an international marketing firm on behalf of the focal multinational mechanical engineering firm. Customers were invited to participate in the survey by email. The surveying was carried out during the period from January $23^{\text {rd }}$ to February $15^{\text {th }}, 2013$ (proportional-stratified sampling). Respondents included customers from seven countries (UK, Belgium, China, Denmark, Switzerland, Turkey, Finland), who were asked to reply to a total of 54 questions (scales in the original questionnaire ranged from 1-10 for all items except for SOW, which was rated from 0-100 in increments of 10). Table 1 displays the key perceptual constructs and the underlying survey questions.

Tables 1 and 2 about here

In total, 5992 customers were contacted, $21 \%$ of which responded, resulting in a sample size of 1,229 responses. From the complete questionnaire, we extracted that subset of items which was deemed relevant to address the above hypotheses (Table 2 for a description of items). Table 2 shows 
that, overall, satisfaction and loyalty are scoring highest, and customers perceive influence on supplier innovation (perceived participatory innovation: PI) the lowest. The correlation matrix (not shown here due to space constraints) suggests that questions which are concerned with the perception of the supplier correlate on a significant level $(\alpha<0.01$, two-tailed $)$ to a different but exclusively positive degree. This does, however, not apply to the SOW (measured in terms of customers' percentage of total procurement within the last year purchased from the focal supplier), which does not correlate significantly with several of the perception-related items, including perceived customer influence on supplier innovation. Further, significant correlation with the SOW can be observed for satisfaction and attitudinal loyalty, though at relatively low levels.

The second data set employed includes information on net sales, gross profit, sales cost and actual quantities sold for the year 2013. In the following, we present descriptive statistics for the sales data set, including information on four items, net sales, gross profit, sales cost and quantity sold. For the purpose of the upcoming analysis, only net sales and gross profit will be discussed further $(\mathrm{n}=633)$. As a next step, we calculate the fractional profit which is used as a metric incorporating both profit and total sales, and hence the cost of sales as well. This profitability ratio (gross profit over net sales) is considered for analyzing the focal firm' performance, since it includes the trade-off between sales costs and profitability. The table of descriptive statistics matching the sales data set with the stated preference data (Table 3) presents a positive picture of the firm, as the majority of entries are distributed in the increasingly profitable half of the spectrum.

\section{Table 3 about here}

\subsection{Analysis}

\subsubsection{Latent class analysis}


Latent class analysis (LCA) (Hagenaars \& McCutcheon 2002) is first employed to explore segmentation according to customer perceptions, with the aim to identify novel (latent) constructs to describe related perception variables. This segmentation exercise enables us not only to inquire whether or not customers perceive the focal firm more consistently positive than negative, but also to identify which specific latent constructs are responsible for customers' overall perception of the focal firm. The analysis suggests five unobservable classes (Table 4) through which customers can be characterized, ranging from $31 \%$ to $6 \%$ of all responses.

\section{Table 4 about here}

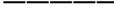

The different sizes of the five classes highlight the importance of taking heterogeneity of customer perceptions into account. Even though customers appear to have a rather positive perception of the focal firm overall (section 3.1.), the LCA underlying

Figure suggests classes with relatively low perception scores for the pricing item, for the item innovation \& customer orientation and for the item reflecting marketing \& information. All but one of the intra-class means are exceeding the median of the scale in Figure 2. The focal firm is therefore perceived favourable by its customers in all items except for pricing in the class with the lowest perception levels. Notable is also that two classes below the mean are distinctly different from the other almost circular rings, showing significantly lower values for the pricing and innovation \& customer orientation items. 
Figure 2 and 3 about here

Considering Figure 3, the enthusiasts show high perception levels across all items, but particularly high scores in terms of loyalty and assessment of the supplier's reputation. These customers represent the second largest latent class. They spend on average the largest SOW with the supplier, and are also among the most profitable class. Interestingly, the sympathetic customer group appears more profitable, but is also characterized by a smaller SOW compared to enthusiasts. Sympathetic customers are also highly loyal, but score the supplier lower in terms of pricing assessment, a trend that intensifies as we move lower down the perception scale. Similarly, the supplier is ranked increasingly lower in terms of its innovativeness, compared to the other items. What is more, perception scores in relation to e-business (combined construct of perceived overall efficiency of the focal firm's e-business platform and perceived ability to meet customer's e-business requirements) remain relatively resilient, similar to perception metrics regarding order handling. The sceptics score the focal firm relatively high in terms of these two items, but nevertheless see their class profitability at its lowest point. Members of this class seem to receive costly attention from the supplier, bringing down supplier profitability, although no effect on SOW is discernible. This may also explain the slight reduction in the profitability of the dissatisfied customer class.

\subsubsection{Fractional logit models}

In the following sections, we conduct fractional logistic regression analyses in order to assess our hypotheses from section (2). The fractional logit model is an extension of the logistic regression model, hence we use it here to model percentages in terms of the SOW and profitability ratio, where SOW is a number between 0 and 100 and is converted to a fraction (fractional SOW=SOW/100). 
Developed by Papke \& Wooldridge (1996), the fractional logit is based on a generalized linear model (McCullagh \& Nelder 1989). Stated formally (Oberhofer \& Pfaffermayr 2012: 56):

$$
E\left(y_{i} \mid \mathbf{x}_{i}\right)=G\left(\mathbf{x}_{i} \boldsymbol{\beta}\right), i=1, \ldots, N
$$

where $0 \leq \mathrm{y}_{\mathrm{i}} \leq 1$ denotes the dependent variable and (the $1 \times \mathrm{k}$ vector) $\mathbf{x}$ refers to the explanatory variables of observation i. G (.) is typically a distribution function similar to the logistic function

$$
\mathrm{G}(\mathrm{z})=\exp (\mathrm{z}) /(1 \exp (\mathrm{z}))
$$

which maps $z$ to the $(0,1)$ interval. The model employs robust standard errors and a binomial family together with a logit link (Oberhofer et al. 2012: 58; Baum, 2008: 302). To implement this model, we proceed as following: with account profitability and SOW subsequently defined as the dependent variable, the independent variables are entered stepwise into the model. Model fit is evaluated using the procedure outlined by Hosmer et al. (2013), removing independent variables based on the Wald test for individual parameters. As a first step, all independent variables that are not deemed important in light of our hypotheses are removed based on an $\alpha$-level of 0.25 . In the next step, items that are exceeding an $\alpha$-level of 0.1 are removed if they are influencing the remaining parameters at a level below $20 \%$. In this way, confounders to the statistically important and theoretically relevant items can be identified. As a last step, all items removed are subsequently re-introduced step by step, to analyze their status as potential confounders (Bursac et al. 2008). The resulting model is then evaluated using a Pregibon link test and Hosmer \& Lemeshow test adapted for the GLM to assess the correct specification of the model. Finally, the marginal effects of the focal independent items are calculated. In the case of categorical variables, as in our model, a key advantage of using 
marginal effects is that a discrete change, hence the effect of moving along the ranks of a given scale, can be assessed in meaningful ways (Williams 2013).

\section{Fractional logit models for profitability}

\section{SOW and profitability analysis}

Considering first the hypothesized association between SOW and profitability as conjectured from the extended satisfaction-repurchase-profitability chain of Anderson et al. (2000) (Hypothesis 1), we observe a negative association across most ranks (Figure 4). With significant marginal effects, two SOW changes are nevertheless striking: a highly positive association following rank three, and a reversal in the consistently negative association subsequent to rank eight. This finding is interesting in the face of cross-industry evidence from Reinartz et al. $(2000,2002)$, suggesting an inconclusive relationship between loyalty and profitability. Figure 4 thus suggests an interesting non-linearity, in that impacting SOW at low levels and at high levels is associated with an increase in profitability, whereas driving SOW at medium levels is associated with a decrease in profitability. This suggests that increasing SOW can come at a price, while the associated relationship investments can pay off in the longer run. This finding is particularly of interest, since it largely corroborates with evidence from the institutional securities sector (Keinignham et al. 2003) and with other evidence from the review study by Reinartz et al. (2015), suggesting a non-linear and asymmetric relationship across most studies. In sum, we conclude that our results from the global mechanical engineering sector support $H 1$ and complement previous evidence from other industries than mechanical engineering, establishing a non-linear relationship, with increasing returns at higher levels of loyalty.

Figure 4 here

Attitudinal loyalty and profitability 
In light of the extended satisfaction-repurchase-profitability chain framework (Anderson et al. 2000; Mittal et al. 2001), we anticipated that more loyal customers generate higher profits in a non-linear fashion, with increasing returns over time as investment into loyalty is recovered. Considering Figure 5, we observe that ranks up to level three are not statistically significant. Subsequently, most ranks are characterized by positive association of changes in attitudinal loyalty and profitability, except for the interim ranks (from 6 to 7) and the highest rank of attitudinal loyalty (rank 9 to 10).

Figure 5 about here

The substantial shifts regarding profitability between rank 4 and rank 7 from highly positive to highly negative associations suggest that the costs of increasing attitudinal loyalty increase at varying rates, i.e. the marginal costs of raising attitudinal loyalty beyond rank six seem to exceed the marginal benefits from the perspective of the focal supplier. In light of this inconsistently positive association between attitudinal loyalty and supplier profitability, we consider our hypothesis H5.b. as not being supported. Given the nonlinearities identified, our results can, however, be related to previous mixed empirical evidence on the varying costs and benefits of customer relationship management mostly from the banking, telecoms and automobile sectors (e.g. Dwyer et al. 1987; Reinartz et al. 2015).

\section{Perceived customer orientation}

As Figure 6 suggests, greater perceived customer orientation cannot be associated consistently with increasing account profitability. Statistical significance at level $p<0.05$ is observed at all ranks, yet the confidence interval varies widely between 0.65 and 0.06 at rank three, and decreases as ranks increase. In light of the inconsistently positive association between customer orientation and profitability, we conclude that the focal firm has not adopted a distinctive customer orientation, 
which would otherwise likely entail a shift in focus from a product-centric to a customer-centric organization, recognizing that customers are heterogeneous in their needs (Reinartz et al. 2015). Correspondingly, we conclude that Hypothesis $H 2 . b$. is not supported. Furthermore, and while not shown here graphically due to failing statistical significance, we have to refute H3.a. (perceived customer orientation of the supplier is positively and non-linearly associated with SOW). Both findings are of interest in the face of limited evidence from the manufacturing sector, pointing otherwise to a positive relationship between customer orientation and focal firm performance (e.g., Dwyer et al. 1987 for a conceptual framework on buyer-seller relationships; Dorsch et al. 1998 for evidence from 94 manufacturing firms). In light of these findings on customer orientation, we conclude that despite evidence for nonlinearities, customer orientation is not a relevant component of relationship quality in the global mechanical engineering sector.

Figure 6 about here

Perceived product innovativeness, profitability and SOW

Considering Figure 7, the association of perceived innovativeness with profitability over the significant ranks 4 to 10 suggests a u-shape. The confidence interval is narrow, and narrows with increasing ranks. Overall, however, due to the u-shape that documents only a weak positive association toward the highest rank of perceived innovativeness, H2.c. receives only weak support. Increasing perceived product innovativeness is not consistently positively associated with increasing profitability. We thus conclude that, although we have evidence for a non-linear relationship, customers in the global mechanical engineering sector appear to regard a supplier's product innovativeness as a largely irrelevant aspect of relationship quality. To explore the implications of this result relative to those on perceptions not related to innovation, consider the result on perceived 
product innovativeness jointly with two results from additional fractional logit regressions. Because of the overwhelming evidence on loyalty and satisfaction in the literature, these regressions are not discussed in greater detail here. As Appendix 1 (Figures A.1. and A.2). nevertheless suggests, a positive association between customer satisfaction and SOW, as well as between attitudinal loyalty and SOW is significant for higher perceptual ranks, suggesting to accept both H5.a. and H5.b., and to corroborate earlier evidence on the satisfaction-shareholder value link (e.g. Anderson et al. 2004; Gruca et al. 2005; Williams et al. 2011; Simmons 2015; Larivière et al. 2016). Considering these findings on the satisfaction-SOW and attitudinal loyalty-SOW associations together with our evidence regarding perceived product innovativeness (Figure 7, and H2.c.) leads us to suggest that in contrast to earlier work (e.g. Berthon et al. 2004), firms may not necessarily need to trade off a customer loyalty and satisfaction-focus when raising their perceived innovation profile for achieving competitive advantage. Furthermore, our results on perceived innovativeness from the customers' perspective complement previous RBV work (Wang et al. 2016a) that has focused on firm's selfperception of innovation. In particular, Wang et al. (2016a) provided evidence that customer orientation positively affects service as well as product innovativeness.

Figure 7 about here

Given the above insights on perceived innovativeness and account profitability, we next turn to how perceived innovativeness relates to SOW. The corresponding fractional logit model suggests that customers' perception that their supplier is innovative is associated with decreasing SOW for all ranks (Figure 8). This negative association continues over all ranks almost linearly, and is thus rather different from the above other fractional logit model results involving SOW. With marginal effects at all ranks calculated having a statistical significance of $\mathrm{p}<0.001$, our hypothesis $H 3 . b$. that 
customer perception of the supplier being innovative is non-linearly associated with increasing SOW, has therefore to be refuted. This suggests that from the perspective of the customer, perceived product innovativeness does neither seem to be a relevant aspect of relationship quality (e.g. Ford 1980; Dorsch et al. 1998), nor does it support that a greater value of buyer-supplier relationship orientation has been generated through product adaptation as part of a shift from a more transactional toward a relationship orientation (Viio et al. 2016). This inability or irrelevance of converting relational assets into customer value (Srivastava et al. 1998) suggests that frameworks other than a resource-based-view (Barney 1991; Kraaijenbrink et al. 2010) could be more constructive for understanding this specific customer-supplier issue at hand. Furthermore, considering also our second hypothesis related to a supplier's innovativeness, we have to reject $H 4$ (a change in customers' perceived influence on supplier innovation is positively associated with SOW), since the marginal effects are found not to be statistically significant at $p<0.1$. In sum, we have evidence suggesting that customers do not perceive that having a greater influence on a supplier's innovation activities contributes to building the supplier-customer capability profile (Möller et al. 2003). The lack of evidence on the expected association between SOW and perceived influence on supplier innovation furthermore suggests that such perceived influence does not contribute to relationship quality (Ford 1980; Dorsch et al. 1998; Viio et al. 2016), noting that such relationship quality has previously been positively associated with SOW (Dorsch et al. 1998: 132, Hypothesis 1c.).

Figure 8 about here

\section{Discussion and conclusions}

Customer relationship and customer value management research has significantly contributed to our understanding of the role of perceptual customer metrics for supplier performance. Our study 
extends this body of work by incorporating perceptual constructs in behavioral outcomes, focusing on customer-perceived value. The two key behavioral outcomes we investigate are customer account profitability and share of wallet (SOW). The study draws from two conceptual frameworks. On the one hand, from Anderson \& Mittal's (2000) framework underlying a satisfaction-repurchaseprofitability sequence and its adaptation to SOW (Keiningham et al., 2005; Cooil et al., 2007), with its anchoring in attitude-behavior relations models (Ajzen et al. 1980; Mittal et al. 2001). On the other hand, our study invokes the resource-based-view (Wernerfelt 1984; Barney 1991) and its focus on relational assets (Srivastava et al. 1998). The paper provides evidence from the global mechanical engineering sector, contributing to our understanding of the value of customer engagement in new product development and innovation, as well as contributing to the debate on nonlinearities between perceptual constructs and behavioral metrics. Taken together, our results corroborate earlier crossindustry evidence that 'more is not always better' (Ritter \& Walter 2012), a finding that also resonates with previous evidence from the banking sector where better customer evaluations were found not necessarily to translate into greater supplier performance (Leverin \& Liljander 2006).

The paper provides first a latent class analysis (LCA) of customer perceptions, which suggests that it is important to take customers' perceptual heterogeneity into account, since the LCA reveals which specific latent constructs are responsible for customers' overall positive perception of the focal firm. The LCA highlights that the customer group identified as second-highest in its overall perception of the focal firm (sympathetic customers) appears even more profitable compared to that latent customer segment rating the focal firm highest, while the former class is also characterized by a smaller SOW compared to the latter. Strikingly, the segment of dissatisfied customers is not the segment showing the lowest account profitability. The subsequent fractional logistic regression analysis indicates a predominantly negative association of a supplier's product innovativeness, as 
perceived by its customers, with SOW. This suggests that although the focal supplier is perceived as innovative, it has not been successful in aiding the customer base to create value. We also find support for customers perceiving little value in an opportunity to be involved in supplier innovation, as reflected in SOW. One possible explanation for this latter finding rests with the nature of the sector (mechanical engineering with limited evidence of outbound open-innovation practices) and the significant size of the focal firm under investigation, since previous work has documented that inbound open innovation practices are more commonly practiced than outbound practices in large firms (e.g. Chesbrough \& Brunswicker 2013).

Considering our results for both perceptual constructs of innovation further, they seem to provide support for the view that values other than perceived innovativeness may be more important in customer relationship management (e.g. Smals \& Smits 2012; O’Cass \& Ngo 2012). Explanations for our finding of a negative non-linear association between customers' perceived innovativeness of the focal firm and SOW include the greater relative importance that customers place on a focal firm's other competences, such as the focal firm's perceived ability to deal with customer risk concerns (Meunier, 2014). Such buyer perceptions of supply disruption risks, which have elsewhere been explored in the context of supply chain complexity (Ellis et al. 2010), may in our case explain why customers are willing to spend a higher portion of their SOW at a lower level of perceived innovativeness of the focal firm. Considering potential production disruptions, we could also perceive a customer's need for reliability as attributed to established products to be counterbalanced by the perceived risk that switching to more innovative products entails. Such perceived risks (costs) of switching have proved to be increasingly important as customer-organization relationships deepen (Bell, Auh \& Smalley 2005), and for impacting product innovation (Salies 2011). 
Furthermore, our results for both perceptual constructs of innovation suggest that a focus on relational assets as part of the RBV (Srivastava et al. 1998) has limited value for conceptualizing the problem at hand. This latter conclusion contrasts nevertheless with recent insights from Wang et al.'s (2016a) analysis of the effects of customer orientation, though perceived by the supplier, on innovation performance. Wang et al. (2016a) invoke the RBV to suggest that supplier collaboration can be seen as an important resource needed for innovation among Chinese enterprises. Furthermore, considering the nature of the industry from which we conclude that customers' perceptions of the supplier's innovativeness lack positive association with customer account profitability, namely mechanical engineering, this conclusion could be interpreted alongside with predictions from earlier analyses on service firms. Those analyses (e.g. Kelly 1992; Hartline et al. 2000; Alam et al. 2002) suggest that customer orientation plays a more important role to service firms, compared to tangible product firms, to which we count our focal firm. Further, if we consider not only the nature of the industry (service versus manufacturing), but also the nature of the very manufacturing sector itself, our results may be interpreted in the context of Bowen et al.'s (1989) analysis of customer orientation in the manufacturing sector. In the context of Proposition 1, "For manufacturing firms in mature markets, the technical dimensions of customer service may be less important in attaining competitive advantage than for manufacturing firms in emerging or growth markets.", Bowen et al. (1989: 87) suggest that mature markets may limit the significance of the technical dimension of customer service, such as repair services, but enhance the significance of relational dimensions, such as those where customers suggest new product designs and applications. If we consider our empirical evidence from a focal manufacturing firm operating in mature markets, then our conclusion that perceived customer influence on supplier innovation is largely an irrelevant relational dimension with respect to behavioural loyalty would seem to go counter Bowen et al.'s (1989) Proposition 1. Furthermore, Bowen et al.'s (1989: 88) second proposition that “Extensive customer service may be 
required when manufacturing firms are initially entering a market and are trying to overcome the first-mover advantages held by established sellers.", is based on their rationale that in cases where services accompany products, services may reduce the purchase risk in novel markets. Since our evidence comes from a long-established manufacturing enterprise which could be characterized as operating in highly mature markets, where limited first-mover advantages of competitors need to be overcome, our empirics seem support the second Proposition of Bowen et al. (1989).

In light of the limited empirical evidence on the relationship between profitability and perceptual customer constructs, our results regarding customer account profitability are of particular interest. The results suggest that the association between behavioural loyalty and customer account profitability is predominantly negative and non-linear, with increasing returns at higher levels of behavioural loyalty. The predominant negative association at lower levels of behavioural loyalty could be considered in the context of earlier evidence, where customer revenue was found to correlate negatively with customer profitability for unprofitable consumer segments (Keiningham et al. 2005). In contrast to behavioural loyalty, the results for attitudinal loyalty suggest an inconsistently positive association between attitudinal loyalty and supplier profitability. Earlier empirical evidence from the banking, telecoms and automobile sectors is mixed, with both positive negative relationships between attitudinal loyalty and profitability (e.g. Dwyer et al. 1987; Reinartz et al. 2015).

In contrast to the above findings on SOW and customer perceptions regarding the supplier's innovation, our results support the notion that increasing levels of attitudinal loyalty and customer satisfaction can each be associated with rising SOW. The non-linearity with increasing returns observed for the association between customer satisfaction and SOW is noteworthy in the face of Mittal \& Kamakura's (2001) non-linear relationship with increasing returns observed for the 
customer satisfaction-behavior linkage. Earlier evidence of an increasing association between customer satisfaction and outcome (market share and net income) toward higher levels of satisfaction (Finkelman 1993) also concurs with our evidence for a positive and increasing satisfaction-SOW association at higher satisfaction levels. Furthermore, having identified the above nonlinearities between perceptual constructs and behavioral metrics, our results add emphasis to the important nature and role of non-linearities for making investment decisions into customer loyalty along the satisfaction-loyalty-profitability chain (e.g., Anderson et al. 2000; Mittal et al. 2001; Keiningham et al. 2003). As Anderson et al. (2000: 109) highlight, ignoring such non-linearity could lead to incorrectly estimating attribute importance weights and thereby missing the mark in prioritizing efforts to maintain and improve perceptual metrics, such as customer satisfaction. While such non-linearity has been observed in many sectors, a lack of empirical consensus is found on projected asymmetries (Reinartz et al. 2000, 2002). Nevertheless, the review by Reinartz et al. (2015: 149) concludes that the satisfaction-loyalty-profit chain is conceptually sound, while the linkages are far more complex than originally assumed, especially in practice. In terms of managerial implications, our analysis provides several insights. Those in charge of customer relationship management in complex manufacturing companies likely benefit from a more detailed understanding of the nonlinearities between perceptual customer concepts and business performance metrics, focusing on attitudinal loyalty and customer satisfaction: turning customers into performance-relevant advocates may be effectively achieved through data-driven analytics of nonlinearities (e.g., Kennedy 2006). We thus concur with Reinartz et al. (2015: 149) that the industry practice of using customer satisfaction or loyalty as a proxy for profitability is not sufficient. The implication is that a better understanding of nonlinearities between perceptual customer concepts and behavioral metrics could contribute toward more effective customer targeting and thus competitive advantage, as the costs and benefits of customer engagement become more transparent. 
Our results regarding perceptual constructs of innovation also imply that managers need not necessarily trade off a customer-loyalty and satisfaction-focus with raising their company's perceived innovation profile for achieving competitive advantage.

Figure 1: Framework of analysis

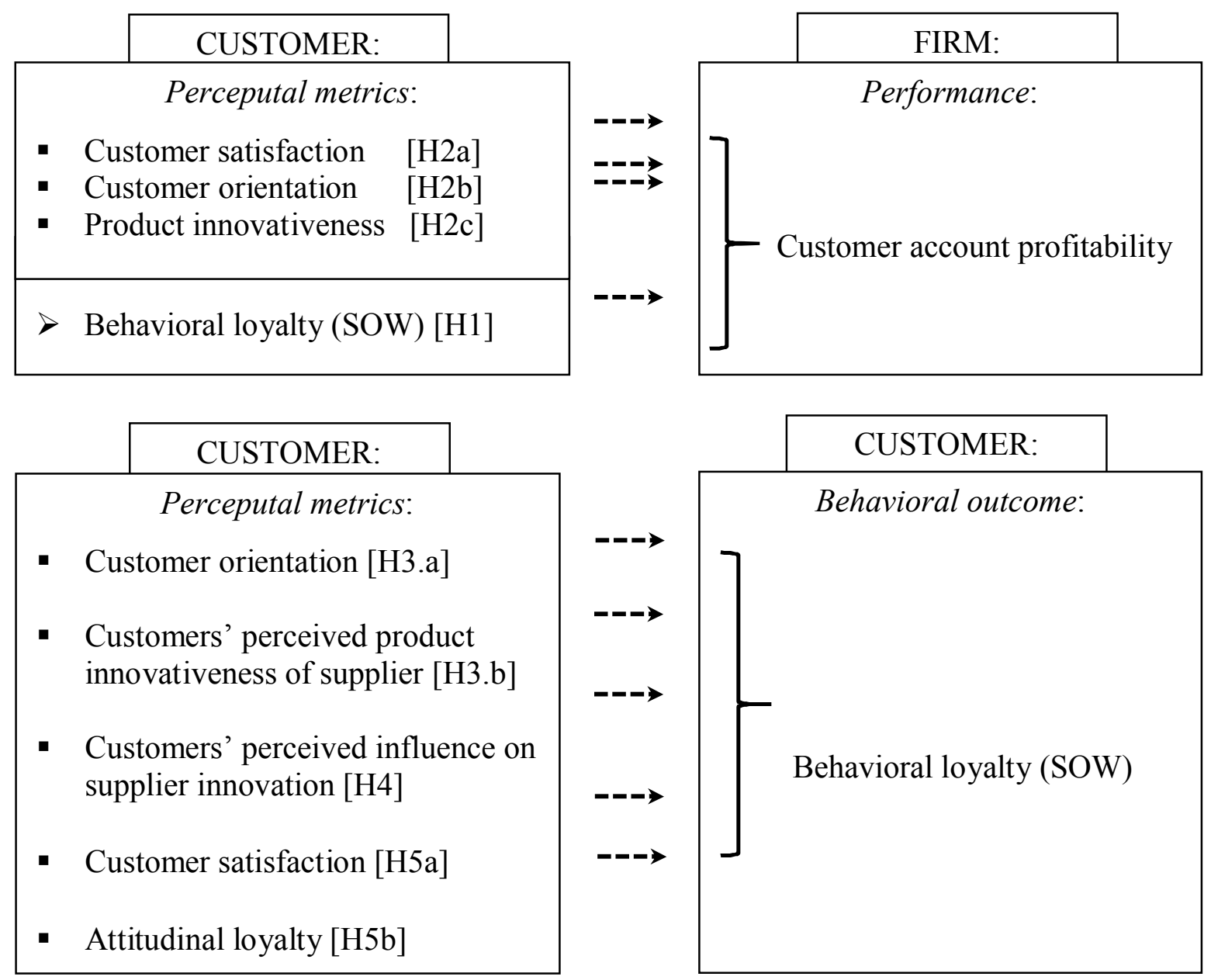

Figure 2: Latent class segmentation by perception levels 

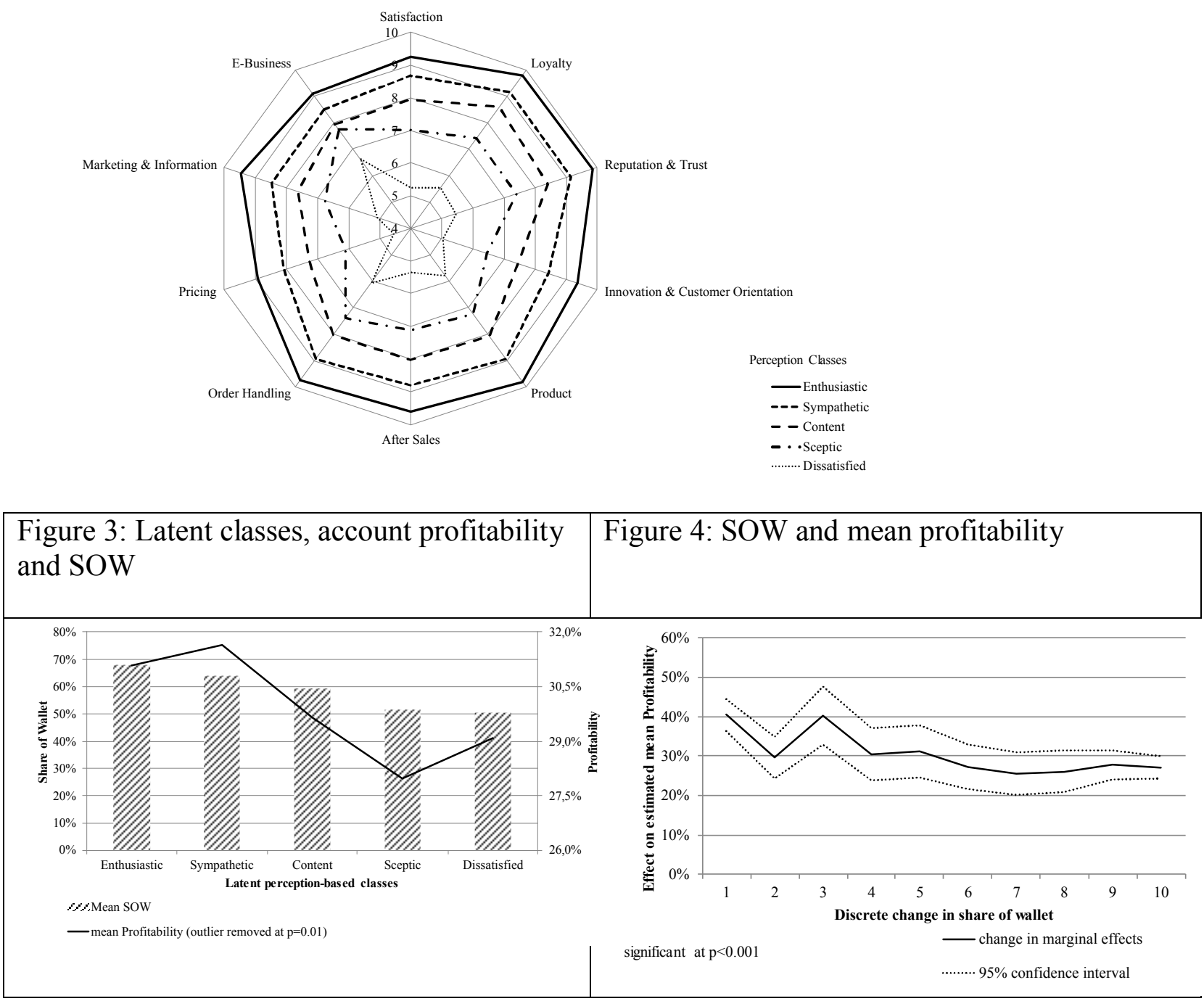

Figure 5: Attitudinal loyalty and mean profitability

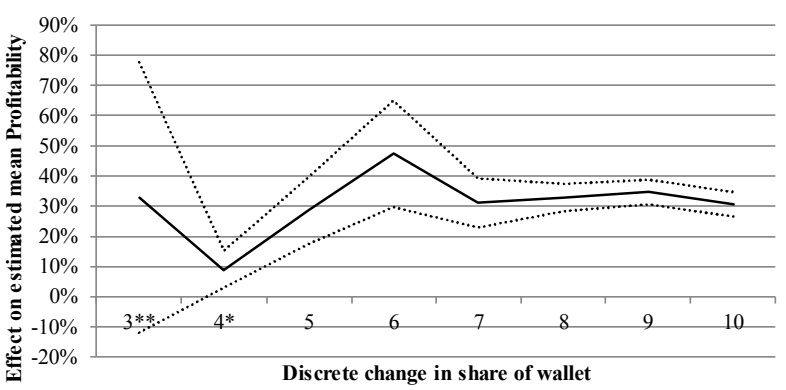

** significant at $\mathrm{p}<0.150$;

* significant at $\mathrm{p}<0.005$;

Discrete change in share of wallet

otherwise at $\mathrm{p}<0.001$
Figure 6: Customer orientation and mean profitability

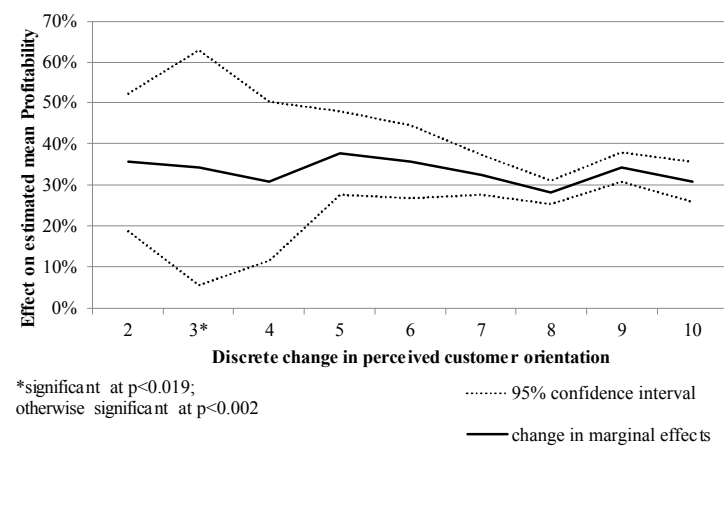




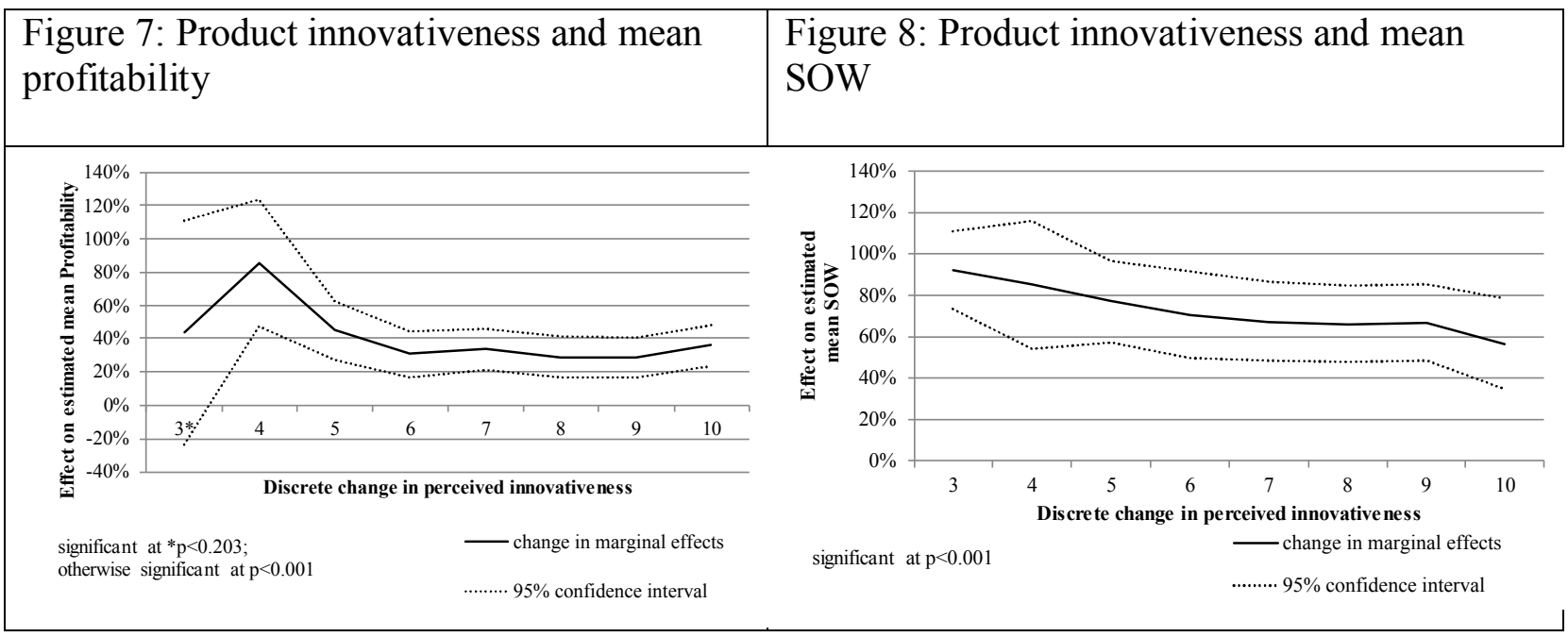

Table 1: Perceptual constructs used for analysis

Perceptual construct

Customer satisfaction

Attitudinal loyalty

Customer orientation (CO)

Product innovativeness (PI)

Customer influence on innovation (CI)
Item (X stands for the name of the focal company) "How satisfied are you with X overall?" "I wish to continue using $X$ as a supplier for my future business."

" $X$ is a customer-oriented company that understands my business." "X develops innovative products." "I have an opportunity to influence the development of future $X$ products, solutions and services."

Table 2: Descriptive statistics of stated preference data

\begin{tabular}{lllllll} 
Item & Mean & SD & Skew & Kurtosis & Min & Max \\
\hline $\begin{array}{l}\text { Customer } \\
\text { satisfaction }\end{array}$ & 8.30 & 1.50 & -1.87 & 8.07 & 1 & 10 \\
$\begin{array}{l}\text { Attitudinal } \\
\text { loyalty }\end{array}$ & 8.74 & 1.49 & -1.99 & 8.50 & 1 & 10 \\
CO & 8.16 & 1.63 & -1.49 & 6.14 & 1 & 10 \\
PI & 8.13 & 1.41 & -1.07 & 4.98 & 2 & 10 \\
CI & 6.83 & 2.18 & -.89 & 3.45 & 1 & 10 \\
SOW & 60.41 & 36.21 & -.3898 & 1.534 & 0 & 100
\end{tabular}

Table 3: Focal items from the CPS in the Sales Data context $(n=616)$

\begin{tabular}{lllllll} 
Item & Mean & SD & Skew & Kurtosis & Min & Max \\
\hline Satisfaction & 8.30 & 1.41 & -1.89 & 8.16 & 1 & 10 \\
Loyalty & 8.77 & 1.37 & -1.84 & 7.67 & 2 & 10 \\
CO & 8.13 & 1.59 & -1.48 & 6.14 & 1 & 10 \\
PI & 8.13 & 1.34 & -.98 & 4.69 & 2 & 10
\end{tabular}




$\begin{array}{lllllll}\text { CI } & 6.82 & 2.13 & -.92 & 3.70 & 1 & 10 \\ \text { SOW } & 60.70 & 35.11 & -.38 & 1.59 & 0 & 100\end{array}$

Table 4 - Characteristics of latent classes

Class 1 Class 2 Class 3 Class 4 Class 5 Full

\begin{tabular}{|c|c|c|c|c|c|c|}
\hline & & & & & & Sample \\
\hline $\mathbf{N}$ & 168 & 293 & 305 & 163 & 58 & 987 \\
\hline $\begin{array}{l}\% \text { of full } \\
\text { sample }\end{array}$ & $17 \%$ & $30 \%$ & $31 \%$ & $17 \%$ & $6 \%$ & $100 \%$ \\
\hline $\begin{array}{l}\text { Mean } \\
\text { perception }\end{array}$ & 9,49 & 8,71 & 7,94 & 7,06 & 5,47 & 8,14 \\
\hline $\begin{array}{l}\text { Assigned } \\
\text { description of }\end{array}$ & High & $\begin{array}{l}\text { High- } \\
\text { Average }\end{array}$ & Average & $\begin{array}{l}\text { Low- } \\
\text { Average }\end{array}$ & Low & \\
\hline
\end{tabular}

Appendix 1

Figure A.1: Customer satisfaction and SOW

\section{References}

Ajzen, I., \& Fishbein, M. (1980). Understanding Attitudes and Predicting Social Behavior, Prentice-Hall, Englewood Cliffs, N.J .

Aksoy, L. (2014). Linking satisfaction to share of deposits: an application of the wallet allocation rule. International Journal of Bank Marketing, 32(1), 28-42.

Alam, I., \& Perry, C. (2002). Acustomer-oriented new service development process. Journal of Service Marketing, 16(6), 515-534.

Almirall, E., \& Casadesus-Masanell, R. (2010). Open versus closed innovation: A model of discovery and divergence. Academy of Management Review, 35(1), 27-47.

Anaza, N. A., \& Rutherford, B. (2012). How organizational and employee-customer identification, and customer orientation affect job engagement. Journal of Service Management, 23(5), 616-639.

Anderson, E. \& Mittal, V. (2000). Strengthening the Satisfaction-Profit Chain. Journal of Service Research, 3(2), 10720.

Anderson, E.W., Fornell, C. \& Mazvancheryl, S.K. (2004). Customer satisfaction and shareholder value. Journal of Marketing, 68, 172-85.

Appiah-Adu, K., and Singh, S. (1998). Customer orientation and performance: a study of SMEs. Management Decision, 36(6), 385-394.

Arnould, E. J. (2008). Service-dominant logic and resource theory. Journal of the Academy of Marketing Science, $36(1), 21-24$. 
Arslanagic-Kalajdzic, M., \& Zabkar, V. (2015). The external effect of marketing accountability in business relationships: Exploring the role of customer perceived value. Industrial Marketing Management, 46, 83-97.

Atuahene-Gima, K. (1995). An exploratory analysis of the impact of market orientation on new product performance a contingency approach. Journal of Product Innovation Management. 12(4), 275-293.

Atuahene-Gima, K. (1996). Market orientation and innovation. Journal of Business Research. 35(2), 93-103.

Barney, J. B. (1991). Firm Resources and Sustained Competitive Advantage. Journal of Management, 17, 99-120.

Barney, J. B., Ketchen, D. J., \& Wright, M. (2011). The future of resource-based theory revitalization or decline? Journal of Management, 37(5), 1299-1315.

Baum, C. (2008). Stata tip 63: Modeling proportions. Stata Journal, 8(2), 299-303.

Baxter, R., \& Matear, S. (2004). Measuring intangible value in business-to-business buyer-seller relationships: An intellectual capital perspective. Industrial Marketing Management, 33(6), 491-500.

Beckers, S. F., van Doorn, J., \& Verhoef, P. C. (2017). Good, better, engaged? The effect of company-initiated customer engagement behavior on shareholder value. Journal of the Academy of Marketing Science, 1-18.

Bell, S. J., Auh, S., \& Smalley, K. (2005). Customer relationship dynamics: service quality and customer loyalty in the context of varying levels of customer expertise and switching costs. Journal of the Academy of Marketing Science, 33(2), 169-183.

Berthon, P., Mac Hulbert, J., \& Pitt, L. (2004). Innovation or customer orientation? An empirical investigation. European Journal of Marketing, 38(9/10), 1065-1090.

Blut, M., Evanschitzky, H., Backhaus, C., Rudd, J., \& Marck, M. (2016). Securing business-to-business relationships: The impact of switching costs, Industrial Marketing Management, 52, 82-90.

Blocker, C. P., Flint, D. J., Myers, M. B., \& Slater, S. F. (2011). Proactive customer orientation and its role for creating customer value in global markets. Journal of the Academy of Marketing Science, 39(2), 16-233

Bowen, D. E., Siehl, C., \& Schneider, B. (1989). A framework for analyzing customer service orientations in manufacturing. Academy of Management Review, 14(1), 75-95.

Brockman, B. K., Jones, M. A., \& Becherer, R. C. (2012). Customer orientation and performance in small firms: Examining the moderating influence of risk-taking, innovativeness, and opportunity focus. Journal of Small Business Management, 50(3), 429-446.

Brodie, R. J., Hollebeek, L. D., Juric, B., \& Ilic, A. (2011). Customer engagement: conceptual domain, fundamental propositions, and implications for research. Journal of Service Research, 14(3), 252-271.

Brodie, R. J., Ilic, A., Juric, B., \& Hollebeek, L. (2013). Consumer engagement in a virtual brand community: An exploratory analysis. Journal of Business Research, 66(1), 105-114.

Buoye, A. (2016). An examination of relative satisfaction and share of wallet: Investigating the impact of country and customer characteristics. Journal of Service Theory and Practice, 26(3), 297-314.

Bursac, Z., Gauss, C. H., Williams, D. K., \& Hosmer, D.W. (2008). Purposeful selection of variables in logistic regression. Source Code for Biology and Medicine, 3(1), 1.

Cannon, J. P., \& Homburg, C. (2001). Buyer-supplier relationships and customer firm costs. Journal of Marketing, 65(1), 29-43.

Carlson, J., O'Cass, A., \& Ahrholdt, D. (2015). Assessing customers' perceived value of the online channel of multichannel retailers: A two country examination. Journal of Retailing and Consumer Services, 27, 90-102.

Chesbrough, H., \& Brunswicker, S. (2013). Managing open innovation in large firms. Survey report - executive survey on open innovation. Stuttgart: Fraunhofer Verlag.

Cooil, B., Keiningham, T., Aksoy, L., \& Hsu, M. (2007). A longitudinal analysis of customer satisfaction and share of wallet: investigating the moderating effect of customer characteristics. Journal of Marketing, 71(1), 67-83.

Dagger, T. S., \& David, M.E. (2012). Uncovering the real effect of switching costs on the satisfaction-loyalty association: The critical role of involvement and relationship benefits. European Journal of Marketing, 46(3/4), 447-468.

Day, G., \& Wensley, R. (1988). Assessing advantage: a framework for diagnosing competitive superiority. The Journal of Marketing, 52(2), 1-20.

Desouza, K., Awazu, Y., Jha, S., Dombrowski, C., Papagari, S., Baloh, P., \& Kim, J.Y. (2008). Customer-driven innovation. Research-Technology Management, 51(3), 35-44.

Deshpandé, R., Farley, J. U., \& Webster, F.E. Jr. (1993). Corporate culture, customer orientation, and innovativeness in Japanese firms: a quadrad analysis. Journal of Marketing, 57(1), 23-37.

Dierickx, I. \& Cool, K. (1989). Asset stock accumulation and sustainability of competitive advantage," Management Science, 35(12), 1504-1514.

Dorsch, M. J., Swanson, S.R. \& Kelley, S.W. (1998). The role of relationship quality in the stratification of vendors as perceived by customers. Journal of the Academy of Maketing Science, 26 (2), 128-42. 
Dunphy, S., \& Herbig, P. (1995). Acceptance of innovations: the customer is the key! The Journal of High Technology Management, 6(2), 193-209.

Dwyer, F. Robert, Paul H. Schurr, \& Oh, S. (1987). Developing Buyer-Seller Relationships. Journal of Marketing, 51, $11-27$.

Eagly, A. H., \& Chaiken, S. (1993). The psychology of attitudes. San Diego: Harcourt Brace Jovanovich College Publishers.

EC (2016). Mechanical Engineering. http://ec.europa.eu/growth/sectors/mechanical-engineering en, acc. 21/01/ 2016.

Eggert, A., \& Ulaga, W. (2010). Managing customer share in key supplier relationships. Industrial Marketing Management, 39(8), 1346-1355.

Eisenhardt, K. M., \& Schoonhoven, C.B. (1996). Resource-based view of strategic alliance formation: Strategic and social effects in entrepreneurial firms. Organization Science, 7(2), 136-150.

Ellis, S. C., Henry, R. M., \& Shockley, J. (2010). Buyer perceptions of supply disruption risk: a behavioral view and empirical assessment. Journal of Operations Management, 28(1), 34-46.

Ellis, S. C., Henke, J. W., \& Kull, T. J. (2012). The effect of buyer behaviors on preferred customer status and access to supplier technological innovation: An empirical study of supplier perceptions. Industrial Marketing Management, 41(8), 1259-1269.

Finkelman, D. P. (1993). Crossing the 'Zone of Indifference'. Marketing Management, 2 (3), 22-32.

Fishbein M, \& Ajzen, I. (1975). Belief, attitude, intention and behavior: An introduction to theory and research, Reading, Mass.: Addison-Wesley.

Flint, D. J., Blocker, C. P., \& Boutin, P. J. (2011). Customer value anticipation, customer satisfaction and loyalty: An empirical examination. Industrial Marketing Management, 40(2), 219-230.

Ford, D. (1980). The Development of Buyer-Seller Relationships in Industrial Markets. European Journal of Marketing, 14(5/6), 339 - 353.

Fornell, C., Johnson, E. W., Anderson, J. Cha, \& Bryant, B.E. (1996). The American Customer Satisfaction Index: Nature, Purpose, and Findings. Journal of Marketing, 60, 7-18.

Fornell, C., Morgeson III, F. V., \& Hult, G.T. (2016). Stock returns on customer satisfaction do beat the market: gauging the effect of a marketing intangible. Journal of Marketing, 80(5), 92-107.

Foss, N. J. (2011). Why micro-foundations for resource-based theory are needed and what they may look like. Journal of Management, 37(5), 1413-1428.

Foss, N. J., Laursen, K., \& Pedersen, T. (2011). Linking Customer Interaction and Innovation: The Mediating Role of New Organizational Practices. Organization Science, 22(4), 980-999.

Foss, N. J., \& Lindenberg, S. (2013). Microfoundations for strategy: A goal-framing perspective on the drivers of value creation. The Academy of Management Perspectives, 27(2), 85-102.

Frambach, R. T., Fiss, P. C., \& Ingenbleek, P.T. (2016). How important is customer orientation for firm performance? Journal of Business Research, 69(4), 1428-1436.

Füller, J., \& Matzler, K. (2007). Virtual product experience and customer participation-A chance for customercentred, really new products. Technovation, 27(6-7), 378-387.

Gardner, T. (2016). Mechanical Engineering in the FY 2016 Budget http://www.aaas.org/fy16budget/mechanicalengineering-fy-2016-budget, accessed July 12, 2016.

Garland, R. (2004). Share of wallet's role in customer profitability. J. of Financial Services Marketing, 8(3), 259-268.

Gemser, G., \& Perks, H. (2015). Co-Creation with Customers: An Evolving Innovation Research Field. Journal of Product Innovation Management, 32(5), 660-665.

Grant, R. M. (1991). The resource-based theory of competitive advantage: implications for strategy formulation. California Management Review, 33(3), 114-135.

Greer, C. R., \& Lei, D. (2012). Collaborative Innovation with Customers: A Review of the Literature and Suggestions for Future Research. International Journal of Management Reviews, 14(1), 63-84.

Grönroos, C. (2011). A service perspective on business relationships: the value creation, interaction and marketing interface. Industrial Marketing Management, 40(2), 240-247.

Gruca, T. \& Rego, L. (2005). Customer satisfaction, cash flow and shareholder value. J. of Marketing, 69, 115-130.

Guadagni, P. \& Little, J. (1983). A logit model of brand choice calibrated on scanner data. Marketing Science, 2(3), $203-238$.

Guo, L., Xiao, J. J., \& Tang, C. (2009). Understanding the psychological process underlying customer satisfaction and retention in a relational service. Journal of Business Research, 62(11), 1152-1159.

Gupta, S., \& Zeithaml, V. (2006). Customer metrics and their impact on financial Performance. Marketing Science, 25(6), 718-739.

Hagenaars, J. A. \& McCutcheon, A. L. (2002). Applied Latent Class Analysis, Cambridge Univ. Press, UK. 
Harmeling, C. M., Moffett, J. W., Arnold, M. J., \& Carlson, B. D. (2017). Toward a theory of customer engagement marketing. Journal of the Academy of Marketing Science, 45(3), 312-335.

Hartline, M.D., Maxham III, J.G., \& McKee, D.O. (2000). Corridors of influence in the dissemination of customeroriented strategy to customer contact service employees. Journal of Marketing, 64(2), 35-50.

Homburg, C., Koschate, N., \& Hoyer, W. D. (2005). Do satisfied customers really pay more? A study of the relationship between customer satisfaction and willingness to pay. Journal of Marketing, 69(2), 84-96.

Homburg, C., Droll, M., \& Totzek, D. (2008). Customer prioritization: does it pay off, and how should it be implemented?. Journal of Marketing, 72(5), 110-130.

Hooley, G., Broderick, A., \& Möller, K. (1998). Competitive positioning and the resource-based view of the firm. Journal of Strategic Marketing, 6(2), 97-116.

Hosmer, D. W., Lemeshow, S., \& Sturdivant, R. X. (2013). Applied logistic regression (Vol. 398), Hoboken, New Jersey: John Wiley \& Sons.

Jaworski, B. J., \& Kohli, A. K. (1993). Market orientation: antecedents and consequences. J. of Marketing, 53-70.

Jean, R. J., Sinkovics, R. R., \& Hiebaum, T. P. (2014). The effects of supplier involvement and knowledge protection on product innovation in customer-supplier relationships: a study of global automotive suppliers in China. Journal of Product Innovation Management, 31(1), 98-113.

Jones,T.O., \& Sasser,W. E. (1995). Why satisfied customer defect. Harvard Business Review, 71, 88-99.

Kahneman, D. (1992). Reference points, anchors, norms, and mixed feelings. Organizational Behavior and Human Decision Processes, 51(2), 296-312.

Kamakura, W. A., Mittal, V., De Rosa, F., \& Mazzon, J. A. (2002). Assessing the service-profit chain. Marketing Science, 21(3), 294-317.

Kamakura, W., Mela, C. F., Ansari, A., Bodapati, A., Fader, P., Iyengar, R., Naik, P., Neslin, S., Sun, B., Verhoef, P.C., Wedel, M. \& Wilcox, R. (2005). Choice models and customer relationship management. Marketing Letters, 16(3-4), 279-291.

Kazadi, K., Lievens, A., \& Mahr, D. (2016). Stakeholder co-creation during the innovation process: Identifying capabilities for knowledge creation among multiple stakeholders. Journal of Business Research, 69(2), 525-540.

Keiningham, T. L., Perkins-Munn, T., \& Evans, H. (2003). The Impact of Customer Satisfaction on Share-of-Wallet in a Business-to-Business Environment. Journal of Service Research, 6(1), 37-50.

Keiningham, T. L., Perkins-Munn, T., Aksoy, L. \& Estrin, D. (2005). Does customer satisfaction lead to profitability? The mediating role of share-of-wallet. Managing Service Quality: An International Journal, 15(2), 172-181.

Keiningham, T. L., Cooil, B., Aksoy, L., Andreassen, T. W., \& Weiner, J. (2007). The value of different customer satisfaction and loyalty metrics in predicting customer retention, recommendation, and share-of-wallet. Managing Service Quality: An International Journal, 17(4), 361-384.

Keiningham, T. L., Aksoy, L., Komarova, Y. A., \& Nejad, M. (2015a). The chain of effects from customer satisfaction to customer profitability. Handbook of Research on Customer Equity in Marketing, Kumar, V. and D. Shah (eds.), Edgar Elgar, Cheltenham, UK, Chp. 11, 265-282.

Keiningham, T. L., Cooil, B., Malthouse, E. C., Lariviere, B., Buoye, A., Aksoy, L., \& De Keyser, A. (2015b). Perceptions are relative: an examination of the relationship between relative satisfaction metrics and share of wallet. Journal of Service Management, 26(1), 2-43.

Keiningham, T.L., Aksoy, L., Williams, L. \& Buoye, A. (2015c). The Wallet Allocation Rule: Winning the Battle for Share, John Wiley \& Sons: New York, NY.

Kelly, S.W. (1992). Developing customer orientation among service employees. Journal of the Academy of Marketing Science, 20, 27-36.

Kennedy, A. (2006). Electronic customer relationship management (eCRM): Opportunities and challenges in a digital world. Irish Marketing Review, 18(1/2), 58.

Keränen, J., \& Jalkala, A. (2013). Towards a framework of customer value assessment in B2B markets: An exploratory study. Industrial Marketing Management, 42(8), 1307-1317.

Kleinaltenkamp, M., Plinke, W., \& Söllner, A. (2015). Theoretical Perspectives of Business Relationships: Explanation and Configuration, in: Kleinaltenkamp, M., Plinke, W., \& Söllner, A. (eds.) Business Relationship Management and Marketing: Mastering Business Markets. Berlin: Springer, 27-54, ISBN 978-3-662-43856-5.

Kostopoulos, K., Papalexandris, A., Papachroni, M., \& Ioannou, G. (2011). Absorptive capacity, innovation, and financial performance. Journal of Business Research, 64(12), 1335-1343.

Kraaijenbrink, J., Spender, J. C., \& Groen, A. J. (2010). The resource-based view: a review and assessment of its critiques. Journal of Management, 36(1), 349-372.

Kumar, V., Dalla Pozza, I., \& Ganesh, J. (2013). Revisiting the satisfaction-loyalty relationship: empirical generalizations and directions for future research. Journal of Retailing, 89(3), 246-262. 
Kumar, V., \& Pansari, A. (2015). Measuring the benefits of employee engagement. MIT Sloan Management Review, 56(4), 67.

Kumar, V., \& Pansari, A. (2016). Competitive advantage through engagement. Journal of Marketing Research, 53(4), 497-514.

Kumar, V., \& Reinartz, W. (2016). Creating enduring customer value. Journal of Marketing, 80(6), 36-68.

Lapierre, J. (2000). Customer-perceived value in industrial contexts. Journal of Business \& Industrial Marketing, $15(2 / 3), 122-145$.

Larivière, B. (2008). Linking Perceptual and Behavioral Customer Metrics to Multiperiod Customer Profitability. Journal of Service Research, 11(1), 3-21.

Larivière, B., Keiningham, T. L., Aksoy, L., Yalçin, A., Morgeson III, F. V., \& Mithas, S. (2016). Modeling Heterogeneity in the Satisfaction, Loyalty Intention, and Shareholder Value Linkage: A Cross-Industry Analysis at the Customer and Firm Levels. Journal of Marketing Research, 53(1), 91-109.

Lemon, K. N., \& Verhoef, P. C. (2016). Understanding customer experience throughout the customer journey. Journal of Marketing, 80(6), 69-96.

Leverin, A., \& Liljander, V. (2006). Does relationship marketing improve customer relationship satisfaction and loyalty? International Journal of Bank Marketing, 24(4), 232-251.

Lilien, G. L. (2016). The B2B Knowledge Gap," International Journal of Research in Marketing, 33(3), 543-556.

Lindgreen, A., Hingley, M. K., Grant, D. B., \& Morgan, R. E. (2012). Value in business and industrial marketing: Past, present, and future. Industrial Marketing Management, 41(1), 207-214.

McCullagh, P. \& Nelder, J. A. (1989). Generalized Linear Models, 2nd ed. London: Chapman and Hall.

Meunier, G. (2014). Risk Aversion and Technology Portfolios. Review of Industrial Organization, (December), 1-21.

Meyer-Waarden, L. (2007). The effects of loyalty programs on customer lifetime duration and share of wallet. Journal of Retailing, 83(2), 223-236.

Mittal, W. T. Ross, \& Baldasare, P. M. (1998). The Asymmetric Impact of Negative and Positive Attribute-Level Performance on Overall Satisfaction and Repurchase Intentions. Journal of Marketing, 62 (January), 33-4.

Mittal, V., \& Kamakura, W. A. (2001). Satisfaction, repurchase intent, and repurchase behavior: Investigating the moderating effect of customer characteristics. Journal of Marketing Research, 38(1), 131-142.

Mittal, V., Anderson, E. W., Sayrak, A., \& Tadikamalla, P. (2005). Dual emphasis and the long-term financial impact of customer satisfaction. Marketing Science, 24(4), 544-555.

Mittal, V., Han, K., Lee, J. Y., Im, B., \& Sridhar, S. (2017). Attribute-Level Satisfaction, Overall Customer Satisfaction, and Performance Outcomes in Business-to-Business Firms. https://ssrn.com/abstract=2964334.

Möller, K. K., and P. Törrönen, P. (2003). Business suppliers' value creation potential: A capability-based analysis. Industrial Marketing Management, 32(2), 109-118.

Najafi-Tavani, S., Sharifi, H., \& Najafi-Tavani, Z. (2016). Market orientation, marketing capability, and new product performance: The moderating role of absorptive capacity. Journal of Business Research, 69(11), 5059-5064.

Narver, J. C., \& Slater, S. (1990). The effect of a market orientation on business profitability. J. of Marketing, 20-35.

Naumann, E., Williams, P., \& Khan, M. S. (2009). Customer satisfaction and loyalty in B2B services: directions for future research. The Marketing Review, 9(4), 319-333.

Neslin, S., Neslin, Grewal, D., Leghorn, R., Shankar, V., Teerling, M., Thomas, J. \& Verhoef, P. (2006). Challenges and Opportunities in Multichannel Customer Management. Journal of Service Research, 9(2), 95-112.

Oberhofer, H., \& Pfaffermayr, M. (2012). Fractional Response Models - A Replication Exercise of Papke and Wooldridge (1996). Contemporary Economics, 6(3), 56.

O'Cass, A., \& Ngo, L. V. (2012). Creating superior customer value for B2B firms through supplier firm capabilities. Industrial Marketing Management, 41(1), 125-135.

Oliver, R. L. (1999). Whence Consumer Loyalty? Journal of Marketing, 63, 33.

Oliver, R. L., Rust, R. T., \& Varki, S. (1997). Customer delight: foundations, findings, and managerial insight. Journal of Retailing, 73(3), 311-336.

Pansari, A., \& Kumar, V. (2017). Customer engagement: the construct, antecedents, and consequences. Journal of the Academy of Marketing Science, 45(3), 294-311.

Papke, L., \& Wooldridge, J. (1996). Econometric methods for fractional response variables with an application to 401 (k) plan participation rates. Journal of Applied Econometrics, 11(February), 619-632.

Park, C., Park, C., Oh, C. H., Oh, C. H., Kasim, A., \& Kasim, A. (2017). Market challenges, learning and customer orientation, and innovativeness in IJVs. International Marketing Review, 34(6), 945-967.

Penrose, E. (1959). The Theory of the Growth of the Firm, New York: John Wiley \& Sons.

Peteraf, M. A. (1993). The cornerstones of competitive advantage: a resource-based view. Strategic Management Journal, 14(3), 179-191. 
Pulles, N. J., Schiele, H., Veldman, J., \& Hüttinger, L. (2016). The impact of customer attractiveness and supplier satisfaction on becoming a preferred customer. Industrial Marketing Management, 54, 129-140.

Qu, R., \& Z. Zhang (2015). Market orientation and business performance in MNC foreign subsidiaries - Moderating effects of integration and responsiveness. Journal of Business Research, 68(5), 919-924.

Prahalad, C. K., \& Ramaswamy, V. (2004). Co-creation experiences: The next practice in value creation. Journal of Interactive Marketing, 18(3), 5-14.

Reichheld, F. (1996). The loyalty effect, Boston: Harvard Business School Press.

Reichheld, F. \& Sasser, W. (1990). Zero defections: quality comes to services. Harvard Business Review, 68, 105111.

Reinartz, W. \& Kumar, V. (2000). On the profitability of long-life customers in a noncontractual setting: An empirical investigation and implications for marketing. Journal of Marketing, 64(4), 17-35.

Reinartz, W., \& Kumar, V. (2002). The mismanagement of customer loyalty. Harvard Business Review, 80(7), 86-94, 125.

Reinartz, W., \& Eisenbeiss, M. (2015). Managing customer loyalty to maximize customer equity. In: Kumar, V. \& D. Shah (eds.), Handbook of Research in Customer Equity in Marketing, Edgar Elgar, Cheltenham, UK, 139-159.

Ritter, T., \& Walter, A. (2012). More is not always better: The impact of relationship functions on customer-perceived relationship value. Industrial Marketing Management, 41(1), 136-144.

Rust, R. T., Moorman, C. \& Dickson, P. R. (2002). Getting returns from service quality: Revenue expansion, cost reduction, or both. Journal of Marketing, 66, 7-24.

Salies, E. (2011). Product innovation when consumers have switiching costs. Working paper No. 2011-07, Observatoire Français des Conjonctures Économiques, Paris.

Schroeder, R. G., Bates, K. A., \& Junttila, M. A. (2002). A resource-based view of manufacturing strategy and the relationship to manufacturing performance. Strategic Management Journal, 23(2), 105-117.

Sampson, S. E., \& Spring, M. (2012). Customer roles in service supply chains and opportunities for innovation. Journal of Supply Chain Management, 48(4), 30-50.

Shamsie, J. \& Mannor, M. J. (2013). Looking inside the dream team: probing into the contributions of tacit knowledge as an organizational resource. Organization Science, 24, 513-529.

Simmons, R. L. (2015). The relationship between customer relationship management usage, customer satisfaction, and revenue. Doctoral dissertation, Walden University, College of Management \& Technology, Minneapolis.

Singh, R. \& Koshy, A. (2011). Does salesperson's customer orientation create value in B2B relationships? Empirical evidence from India. Industrial Marketing Management, 40, 78-85.

Smals, R. G., \& Smits, A. A. (2012). Value for value-The dynamics of supplier value in collaborative new product development. Industrial Marketing Management, 41(1), 156-165.

Sorescu, A., \& Sorescu, S. M. (2016). Customer Satisfaction and Long-Term Stock Returns. Journal of Marketing, 80(5), 110-115

Srivastava, R.K., Shervani, T.A. \& Fahey, L. (1998). Market-based assets and shareholder value: a framework for analysis. Journal of Marketing, 62(1), 2-18.

Steiert, R. (2008). Mechanical engineering: fundamental to most branches of industry, http://www.industriallunion.org/archive/imf/mechanical-engineering-fundamental-to-most-branches-of-industry, acc. 27/01/2016.

Szymanski, David M. \& Henard, D. H. (2001). Customer Satisfaction: A Meta-Analysis of the Empirical Evidence. Journal of the Academy of Marketing Science, 29 (1), 16-35.

Tellis, G. (1988). Advertising loyalty, exposure and brand purchase: A two-stage model of choice. Journal of Marketing Research, 25(2), 134-145.

Tomczyk, P., Doligalski, T., \& Zaborek, P. (2016). Does customer analysis affect firm performance? Quantitative evidence from the Polish insurance market. Journal of Business Research, 69(9), 3652-3658.

Ulaga, W. (2003). Capturing value creation in business relationships: A customer perspective. Industrial marketing management, 32(8), 677-693.

Ulaga, W., \& Chacour, S. (2001). Measuring customer-perceived value in business markets: a prerequisite for marketing strategy development and implementation. Industrial Marketing Management, 30(6), 525-540.

Ulaga, W., \& Eggert, A. (2006). Value-based differentiation in business relationships: Gaining and sustaining keysupplier status. Journal of Marketing, 70(1), 119-136.

Van Doorn, J., \& Verhoef, P. C. (2008). Critical incidents and the impact of satisfaction on customer share. Journal of Marketing, 72(4), 123-142.

Verhoef, P. C., Van Doorn, J., \& Dorotic, M. (2007). Customer value management: an overview and research agenda. Marketing ZFP, 29(2), 105-122.

Verona, G. (1999). A resource-based view of product development. Academy of Management Review, 24(1), 132-142. 
Viio, P., \& Grönroos, C. (2016). How buyer-seller relationship orientation affects adaptation of sales processes to the buying process. Industrial Marketing Management, 52, 37-46.

Von Hippel, E. (1982). Get new products from customers. Harvard Business Review, 117-123.

Von Hippel, E. (2005). Democratizing innovation: The evolving phenomenon of user innovation. Journal Für Betriebswirtschaft, 55(1), 63-78.

Von Krogh, G., Ichijo, K., \& Nonaka, I. (2000). Enabling knowledge creation: How to unlock the mystery of tacit knowledge and release the power of innovation. Oxford University Press.

Voss, G. B., Godfrey, A., \& Seiders, K. (2010). How complementarity and substitution alter the customer satisfactionrepurchase link. Journal of Marketing, 74(6), 111-127.

Walsh, G., Evanschitzky, H., \& Wunderlich, M. (2008). Identification and analysis of moderator variables: investigating the customer satisfaction-loyalty link. European Journal of Marketing, 42(9/10), 977-1004.

Walter, A., Ritter, T., \& Gemünden, H. (2001)Value creation in buyer-seller relationships: Theoretical Considerations and empirical results from a supplier's perspective. Industrial Marketing Management, 30(4), 365-377.

Wang, Q., Zhao, X., \& Voss, C. (2016a). Customer orientation and innovation: A comparative study of manufacturing and service firms. International Journal of Production Economics, 171, 221-230.

Wang, Y., Lee, J., Fang, E., \& Ma, S. (2016b). Project Customization and the Supplier Revenue-Cost Dilemmas: The Critical Roles of Supplier-Customer Coordination. Journal of Marketing, 81(1), 136-154.

Wernerfelt, B. (1984). A resource-based view of the firm. Strategic Management Journal, 5(2), 171-180.

Williams, R. (2013). Marginal Effects for Continuous Variables: Discrete and Instantaneous. Change, 1-12.

Williams, P., \& Naumann, E. (2011). Customer satisfaction and business performance: a firm-level analysis. Journal of Services Marketing, 25(1), 20-32.

Woodruff, R. (1997). Customer value: the next source for competitive advantage. Journal of the Academy of Marketing Science. 25(2), 139-153.

Zablah, A. R., Bellenger, D. N., \& Johnston, W. J. (2004). An evaluation of divergent perspectives on customer relationship management: Towards a common understanding of an emerging phenomenon. Industrial Marketing Management, 33(6), 475-489.

Zhang, H., Liang, X., \& Wang, S. (2016). Customer value anticipation, product innovativeness, and customer lifetime value: The moderating role of advertising strategy. Journal of Business Research, 69(9), 3725-3730. 